\title{
IMPACT OF PEGYLATION ON THE MUCOLYTIC ACTIVITY OF RECOMBINANT HUMAN DEOXYRIBONUCLEASE I IN CYSTIC FIBROSIS SPUTUM
}

Marie-Julie Guichard ${ }^{\mathrm{a}}$, David Kinoo ${ }^{\mathrm{b}}$, Anne-Sophie Aubriot ${ }^{\mathrm{c}}$, Nathalie Bauwens ${ }^{\mathrm{c}}$, Jordane Gouguéa François Vermeulen ${ }^{\mathrm{b}}$, Patrick Lebecque ${ }^{\mathrm{c}}$, Teresinha Leal ${ }^{\mathrm{d}}$, Rita Vanbever ${ }^{\mathrm{a},{ }^{*}}$

${ }^{a}$ Advanced Drug Delivery \& Biomaterials, Louvain Drug Research Institute (LDRI), Université catholique de Louvain, Brussels 1200, Belgium.

${ }^{\mathrm{b}}$ Department of Respiratory Diseases, University Hospitals Leuven, Leuven 3000, Belgium.

${ }^{c}$ Cystic Fibrosis Unit, Cliniques Universitaires St Luc, Université catholique de Louvain, Brussels 1200, Belgium.

${ }^{\mathrm{d}}$ Louvain Center for Toxicology and Applied Pharmacology, Institute of Experimental and Clinical Research (IREC), Université catholique de Louvain, Brussels 1200, Belgium.

* Corresponding author at: Université catholique de Louvain, Louvain Drug Research Institute, Advanced Drug Delivery and Biomaterials, Avenue Emmanuel Mounier 73, Brussels 1200, Belgium. Tel.: +32 276473 25; fax: +32 276473 98. E-mail address: rita.vanbever@uclouvain.be.

\section{Keywords}

Recombinant human deoxyribonuclease I, PEGylation, cystic fibrosis, sputum, rheology.

\begin{abstract}
Highly viscous mucus and its impaired clearance characterize the lungs of patients with cystic fibrosis (CF). Pulmonary secretions of patients with CF display increased concentrations of high molecular weight components such as DNA and actin. Recombinant human deoxyribonuclease I (rhDNase) delivered by inhalation cleaves DNA filaments contained in respiratory secretions and thins them. However, rapid clearance of rhDNase from the lungs implies a daily administration (QD to BID) and thereby a high therapy burden and a reduced patient compliance. A PEGylated version of rhDNase could sustain the presence of the protein within the lungs and reduce its administration frequency. Here, we evaluated the enzymatic activity of rhDNase conjugated to a two-arm $40 \mathrm{kDa}$ polyethylene glycol (PEG) in CF sputa. Rheology data indicated that both rhDNase and PEG40-rhDNase presented similar mucolytic activity in CF sputa and that this activity did not depend on the concentrations of DNA, actin and metal ions within the samples. Quantification of rhDNase and PEG40-rhDNase in CF sputa suggests that PEGylation largely increases the stability of rhDNase in CF respiratory secretions. These results provide support to the development of a long-acting version of rhDNase to treat CF lung disease.
\end{abstract}

\begin{abstract}
Abbreviation
BSA, bovine serum albumin; CF, cystic fibrosis; CFTR, cystic fibrosis transmembrane conductance regulator; EDTA, ethylenediaminethetraacetic; $\mathrm{FEV}_{1}$, forced expiratory volume in one second; F-actin, filamentous actin; G', elastic modulus; G", viscous modulus; G-actin, globular actin; HEPES, 4-(2hydroxyethyl)-1-piperazineethanesulfonic acid; Pa, Pascal; PEG, polyethylene glycol; rhDNase, recombinant human deoxyribonuclease I; SEM, standard error of the mean; Tris, trishydroxymethylaminomethane.
\end{abstract}




\section{Introduction}

Cystic fibrosis (CF) is an inherited disease caused by an autosomal recessive gene defect. The morbidity and mortality in CF is mainly due to the pulmonary phenotype of the disease. Clinically, the effects of $\mathrm{CF}$ in the lungs are cough, expectoration of airway secretions, recurrent lung infections and rapid loss of pulmonary function $(6,29)$.

The airway mucus is a thin and mobile gel that covers the respiratory tissue surface. It is mainly composed of water and biopolymers, such as the mucin, a heavily glycosylated protein (8). The mucus presents a complex physical behavior. It is described as a viscoelastic gel since it possesses both viscosity and elasticity properties (16). Healthy mucus is characterized by low viscosity and elasticity and is easily transported by ciliary beating. Effective mucus clearance is essential for lung health and airway disease can be a consequence of an impaired clearance. Pathologic mucus has higher viscosity and elasticity than normal mucus and is more difficult to clear. The conversion from healthy mobile mucus to diseased mucus can result from many mechanisms such as dehydration, abnormal transepithelial ion transport, increased production of mucin or lysis of inflammatory cells (8). In case of $\mathrm{CF}$, apoptosis of neutrophils and/or neutrophil extracellular traps death (NETosis) increase the extracellular DNA and filamentous actin contents $(7,27)$; thus leading to the 10 to 100 -fold increase of mucus viscoelasticity (22). Consequently, the mucus becomes thick and impaired clearance as well as bacterial growth characterize the lungs of patients with $\mathrm{CF}$ (8). The presence in CF sputa of components such as DNA, proteins, lipids and cations may influence the viscoelastic properties of the respiratory secretions $(5,10,19)$.

The pathologic CF mucus has led to the development of therapeutic medications intended to decrease its stiffness. Inhaled recombinant human deoxyribonuclease I (rhDNase) has proven its mucolytic activity in CF lung disease for many years (13). Shak et al. demonstrated that rhDNase transformed CF sputum from a non-flowing viscous substance to a liquid within minutes (33). Therefore, DNA hydrolysis by rhDNase in CF respiratory secretions leads to reduced sputum viscosity. However, symptomatic rhDNase treatment presents two major limitations: the protein is inhibited by globular actin (G-actin) (36) and it is rapidly cleared from the lungs (18). When the dose of rhDNase of $2.5 \mathrm{mg}$ is inhaled, a concentration of $3 \mu \mathrm{g} / \mathrm{mL}$ is measured in sputum immediately after inhalation and it is reduced to $0.6 \mu \mathrm{g} / \mathrm{mL}$ after two hours. Recently, our laboratory has developed a PEGylated version of rhDNase with a preserved enzymatic activity (11). Conjugation of PEG to proteins has been shown to prolong their residence time within the lungs following pulmonary delivery in animal models $(3,9,15)$. Therefore, PEGylation of rhDNase could sustain the presence of the protein within the lungs following inhalation. The sustained presence of the PEGylated version of rhDNase in the lungs could space rhDNase dosing and improve patient compliance.

The goal of this research was to determine the in vitro mucolytic activity of rhDNase conjugated to a two-arm $40 \mathrm{kDa}$ PEG (PEG40-rhDNase) in sputa from patients with CF. The rheological properties (elastic and viscous moduli) of CF sputa were measured following addition of rhDNase or PEG40rhDNase. DNA and G-actin were quantified by fluorescence labelling and correlated to the visual inspection of samples (mucoid, muco-purulent or purulent sputum). Ion contents, such as calcium, magnesium and potassium, were measured in CF sputum and correlated with its purulence, with G-actin concentration and with the enzymatic activity of rhDNase and PEG40-rhDNase. Finally, non-PEGylated and PEGylated protein contents were measured in CF biological samples following the rheology assay to evaluate their resistance to proteolysis.

\section{Materials and Methods}

\subsection{Material}

rhDNase (Pulmozyme ${ }^{\circledR}$ ) was from Genentech, Inc. (South San Francisco, CA, USA). Two-arm 40 kDa methoxy PEG (PEG40) propionaldehyde was obtained from NOF Corporation (Tokyo, Japan). Unless otherwise stated, chemicals and reagents were from Sigma-Aldrich (St. Louis, MO, USA). The Nterminal site-specific mono-PEGylation of rhDNase was conducted as previously described (11). 


\subsection{Collection of sputum from patients with $\mathrm{CF}$}

CF sputa were collected by expectoration during physiotherapy. Patients over 18 and below 60 years taking Pulmozyme ${ }^{\circledR}$ were included. Twenty-four hours pre-collection of sputum, patients were asked to stop their rhDNase treatment. Sputa were immediately frozen at $-80^{\circ} \mathrm{C}$ after expectoration. Patients under oral corticosteroid treatment, with a forced expiratory volume in one second $\left(\mathrm{FEV}_{1}\right)<40 \%$ of the predicted value and pregnant women were excluded from the study.

\subsection{Characterization of sputum}

Sputa were sorted according to macroscopic appearance into three categories: mucoid for samples that did not present pus, purulent for samples uniformly purulent whether green or yellow and mucopurulent for samples in which purulent and mucoid parts were mixed (31).

\subsection{Determination of the strain range for measurement}

The range of strain associated with non-destructive conditions of the sputum was determined using the rheometer MCR102 (Anton-Paar, Graz, Austria). CF sputa were thawed at room temperature. Six hundred milligrams of sputum were loaded on the rheometer and incubated during 30 minutes at $37^{\circ} \mathrm{C}$ to allow relaxation of the sample (1). The assay was performed using a $50 \mathrm{~mm}$ stain cone plate with a $1^{\circ}$ angle (CP50-1 ${ }^{\circ}$; Anton-Paar). Shear strains between $0.01 \%$ to $1000 \%$ were applied (16). The results were recorded with RheoCompass ${ }^{\mathrm{TM}}$ software (Anton-Paar).

\subsection{Rheology measurement}

CF sputa were thawed at room temperature. Six hundred milligrams of sample were gently mixed with $30 \mu \mathrm{L}$ of rhDNase or PEGylated rhDNase (at $150 \mu \mathrm{g} / \mathrm{mL}$ in $1 \mathrm{mM} \mathrm{CaCl}_{2}, 150 \mathrm{mM} \mathrm{NaCl}$ ) to reach a final concentration of $10 \mu \mathrm{g} / \mathrm{mL}$ in the sputum. Control samples were made of sputum containing $30 \mu \mathrm{L}$ of rhDNase vehicle, without rhDNase. Rheology assays were performed using rheometer MCR102 and a $50 \mathrm{~mm}$ stain cone plate with a $1^{\circ}$ angle $\left(\mathrm{CP} 50-1^{\circ}\right)$. Treated sputum was loaded on the rheometer and incubated at $37^{\circ} \mathrm{C}$ for 60 minutes. Strains between $0.01 \%$ and $10 \%$ were applied at a constant frequency of $10 \mathrm{~Hz}$. Elastic and viscous moduli were recorded with RheoCompass ${ }^{\mathrm{TM}}$ software.

\section{6. rhDNase and PEG40-rhDNase content in CF sputum}

After rheology measurements, sputa were gently collected from the rheometer plate. rhDNase and PEG40-rhDNase were then quantified by ELISA in these collected sputa. Briefly, a 96-well plate was coated using first rabbit polyclonal antibody to human rhDNase (Bio-connect, Huissen, The Netherlands) in $1 \% \mathrm{NaHCO}_{3}$ solution, $\mathrm{pH} 9.6$ at $4^{\circ} \mathrm{C}$ overnight and blocked with $1 \%$ proteins from milk powder in PBS-Tween $0.1 \%$ at $37^{\circ} \mathrm{C}$ for $1 \mathrm{~h}$. Sputum samples were diluted at $1: 1 \mathrm{in}$ PBS, vortexed for 2 minutes and centrifuged at $5000 \mathrm{rpm}, 4^{\circ} \mathrm{C}$ for 10 minutes. Supernatant of samples as well as standards (rhDNase or PEG40-rhDNase) were incubated at $37^{\circ} \mathrm{C}$ for $1 \mathrm{~h}$. Dilutions were done in PBS-Tween $0.1 \%$ $+0.1 \%$ Bovine Serum Albumine (BSA). Biotin-conjugated antibody (same antibody as the one used for coating) and streptavidin-horseradish peroxidase were used for development. Revelation was conducted using Tetramethylbenzidine solution (Thermo Fisher Scientific, Rockford, IL, USA) and stopped with $2 \mathrm{M} \mathrm{H}_{2} \mathrm{SO}_{4}$. The ELISA plate was read at $450 \mathrm{~nm}$ (Multiskan EX, Thermo Fisher Scientific, Rockford, IL, USA).

\subsection{DNA quantification}

DNA contained in CF sputa was quantified using a Quant-iT ${ }^{\mathrm{TM}}$ PicoGreen ${ }^{\circledR}$ dsDNA Assay Kit (ThermoFisher Scientific, Rockford, IL, USA). The protocol from the manufacturer was slightly adapted (12). Twenty $\mathrm{mg}$ of sputum were diluted 10 fold in $0.1 \mathrm{M}$ dithiothreitol. The mixture was vortexed until complete dissolution of the sample. Then, $5 \mu \mathrm{L}$ of the diluted mucus were added to $100 \mu \mathrm{L}$ of $0.1 \mathrm{mM}$ ethylenediaminetetraacetic acid (EDTA), $10 \mathrm{mM}$ trishydroxymethylaminomethane (Tris) buffer at $\mathrm{pH}$ 
8.0. 8.4 $\mu \mathrm{L}$ of the previous solution were diluted in $492 \mu \mathrm{M}$ of TE (Tris-EDTA) $1 \mathrm{x}$ buffer. $500 \mu \mathrm{L}$ of PicoGreen ${ }^{\circledR}$ reagent were added. An aliquot of $200 \mu \mathrm{L}$ was incubated 5 minutes in the dark in a black 96-well plate. Fluorescence was measured with a SpectraMax ${ }^{\circledR}$ M3 multi-mode microplate reader (Molecular Devices, Sunnyval, USA) with $485 \mathrm{~nm}$ excitation and $530 \mathrm{~nm}$ emission filters.

\subsection{In vitro enzymatic activity of rhDNase in presence of actin}

Rheology assays were performed on a salmon testes DNA solution at $6 \mathrm{mg} / \mathrm{mL}$ in $25 \mathrm{mM} \mathrm{4-(2-}$ hydroxyethyl)-1-piperazineethanesulfonic acid (HEPES) at $\mathrm{pH} 7.5$. Actin solution at $320 \mu \mathrm{g} / \mathrm{mL}$ was prepared in $4 \mathrm{mM} \mathrm{CaCl}_{2}, 2 \mathrm{mM} \mathrm{MgCl}, 0.2 \% \mathrm{BSA}, 28 \mathrm{mM} \mathrm{KCl}$ solution at $\mathrm{pH}$ 7.5. $250 \mu \mathrm{L}$ of DNA and $125 \mu \mathrm{L}$ of actin (or actin vehicle, for the condition without actin) were incubated at $37^{\circ} \mathrm{C}$ for 30 minutes. Then, rhDNase solution was added to reach a final concentration of $1 \mu \mathrm{g} / \mathrm{mL}$ rhDNase $(125 \mu \mathrm{L}$; final volume of $500 \mu \mathrm{L}$ ). Viscosity measurements were performed during 30 minutes at $37^{\circ} \mathrm{C}$ using the Modular Compact Rheometer MCR102. A $50 \mathrm{~mm}$ stain cone plate with a $0.5^{\circ}$ angle was used. A solvent trap containing distilled water prevented dehydration of samples during rheological analysis. The experiments were performed in rotational mode at $1000 \mathrm{rpm}$. The results were recorded by RheoCompass ${ }^{\mathrm{TM}}$ software.

\subsection{Actin quantification}

F- and G-actin contained in sputa were quantified using rhodamine-labelled phalloidin fluorescence labeling (2). The sputum was diluted 20 fold in a polymerizing buffer $(150 \mathrm{mM} \mathrm{KCl}, 2 \mathrm{mM} \mathrm{MgCl}, 0.2$ $\mathrm{mM} \mathrm{CaCl}_{2}, 0.2 \mathrm{mM} \mathrm{Na} \mathrm{ATP}_{2} 1 \mathrm{mM}$ DTT, $2 \mathrm{mM}$ Tris at $\mathrm{pH}$ 7.6) during 30 minutes at $37^{\circ} \mathrm{C}$ to allow the polymerization of G-actin (30). Quantification of F-actin was conducted by replacing the polymerizing buffer by a solution containing $0.2 \mathrm{mM} \mathrm{CaCl}_{2}, 0.2 \mathrm{mM} \mathrm{Na}_{2} \mathrm{ATP}, 1 \mathrm{mM} \mathrm{DTT}, 2 \mathrm{mM}$ Tris at $\mathrm{pH}$ 7.6. One $\mu \mathrm{L}$ of $6.6 \mu \mathrm{M}$ rhodamine-labelled phalloidin (ThermoFisher Scientific, Rockford, IL, USA) was added to $25 \mu \mathrm{L}$ of the diluted sample in a black 384-well plate and incubated 1 hour on ice in the dark. The rhodamine-labelled phalloidin was extracted overnight with methanol at $4^{\circ} \mathrm{C}$ in the dark. The fluorescence enhancement was then measured with a SpectraMax ${ }^{\circledR}$ M3 multi-mode microplate reader (Molecular Devices, Sunnyval, USA) with $550 \mathrm{~nm}$ excitation and $580 \mathrm{~nm}$ emission filters. A standard curve of F-actin was prepared by dissolving 1 to $10 \mu \mathrm{g} / \mathrm{mL}$ actin from rabbit muscle in polymerizing buffer and incubating at $37^{\circ} \mathrm{C}$ for 30 minutes.

\subsection{Ion quantification}

Calcium, magnesium and potassium ions were quantified in CF sputa.

Calcium and magnesium: Samples were prepared by dissolving at least $70 \mathrm{mg}$ of CF sputa in 7 times their mass in water. Samples were then vortexed and centrifuged to separate the solid parts from the supernatant containing $\mathrm{Ca}^{2+}$ and $\mathrm{Mg}^{2+}$. The concentrations measurements were performed using an automatic analyzer (Cobas ${ }^{\circledR} 8000$, Roche Diagnostics, Roche, Basel, Switzerland). $\mathrm{Ca}^{2+}$ were assayed with the 5-nitro-5'-methyl-(1,2-bis(o-aminophenoxy)ethan-N,N,N',N'-tetraacetic acid (NM-BAPTA) method. $\mathrm{Mg}^{2+}$ concentration was determined with the use of the xylidyl blue reaction according to the manufacturer's instructions.

Potassium: Samples were prepared by dissolving at least $70 \mathrm{mg}$ of CF sputa in 10 times their mass in water. Samples were then vortexed and centrifuged to separate the solid parts from the supernatant containing $\mathrm{K}^{+}$. Lithium was used as an internal standard. Standard Calib 140/5 electrolytes for in vitro diagnostics use (Instrumentation Laboratory, Bedford, MA, USA) was used as a single standard for calibration. A volume of $20 \mu \mathrm{L}$ of supernatant was then diluted with $2 \mathrm{~mL}$ of lithium sulfate. The analyses were performed in duplicate with a flame photometer (Model 420 Flame Photometer, Sherwood Scientific Ltd, Cambridge, UK) operated in the atomic emission mode, using a propane flame. The concentrations were expressed in $\mathrm{mM}$. 


\section{Results and discussion}

\subsection{Rheology measurements}

Characterization of sputa focuses on two properties: elastic modulus ( $\left.\mathrm{G}^{\prime}\right)$, which measures the tendency for the gel to recover its original shape following stress-induced deformation, and viscous modulus (G"), which represents the resistance of the gel to flow (16). Non-destructive conditions were required to preserve the structure of the sputa $(1,35)$. Therefore, before analyzing the rheological properties of the samples, we determined the linear viscoelastic region of CF sputum in terms of strain, that is, the region of small deformations in which the viscoelastic parameters remain constant (34). Both elastic and viscous moduli were steady between $0.01 \%$ and $1 \%$ of strain. Consequently, in our experiments, CF sputum was only subject to small oscillations to minimize its deformation and thus reflect the mucus rheology in its native state in the lungs (16). A constant frequency of $10 \mathrm{~Hz}$ was also applied to mimic the beat frequency of the cilia motion (28).

The effects of rhDNase and PEG40-rhDNase on the viscoelasticity of CF sputa were then analyzed. Eighteen CF sputa were included in the rheology analysis. The elastic and viscous moduli of the samples after addition of PEG40-rhDNase were similar to the moduli obtained after the addition of the unconjugated protein (Figure 1). As previously reported by Lai et al. (16), CF sputum was more elastic than viscous under oscillatory and controlled shear strain. This was the case for all the three conditions tested: control, rhDNase and PEG40-rhDNase (Figure 1). The mean decrease in sputum elasticity was $43 \pm 8 \%$ for rhDNase and $55 \pm 4 \%$ for PEG40-rhDNase. Similarly, sputum viscosity decreased by $47 \pm$ $6 \%$ and $49 \pm 5 \%$ following addition of rhDNase and PEG40-rhDNase, respectively. Although we obtained a better activity, our results are in good agreement with data reported by Sanders et al. (30). Sanders et al. showed that sputum elasticity decreased by $32 \%$ and sputum viscosity by $17 \%$ following a 20 minutes incubation with rhDNase at a final concentration of $10 \mu \mathrm{g} / \mathrm{mL}$ in case of clinical rhDNaseresponders. In our study, samples were incubated for 60 minutes with rhDNase before rheology measurement (three-times longer than in Sanders et al.) and could thus explain the better activity we observed. Clinical responders to rhDNase therapy and clinical non-responders can be distinguished among patients with CF (32). Thirty percent of patients with CF are qualified as clinical non-responders since their sputa are not degraded by rhDNase whereas sputa from clinical responders are extensively degraded by rhDNase (30). In our study, only patients taking rhDNase and considered as responders were included. 

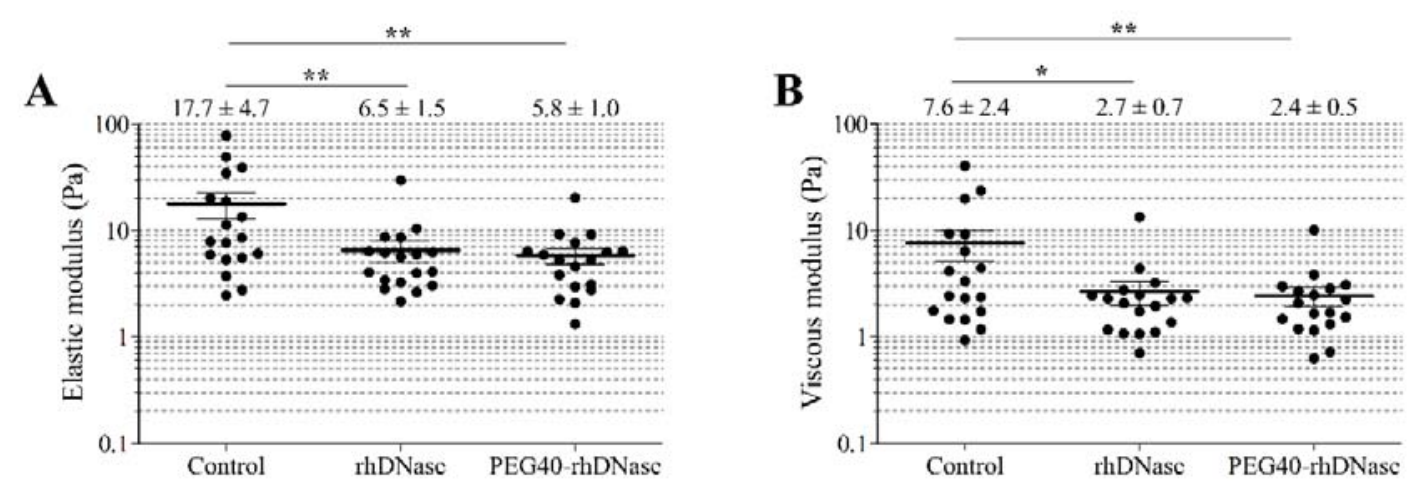

Figure 1: Effect of rhDNase and PEG40-rhDNase on the viscoelasticity of CF sputa ( $n=18$, mean \pm SEM), A. Elastic modulus. B. Viscous modulus, both expressed in Pascal $\left(\mathrm{Pa} ; \mathrm{kg}_{\mathrm{m}} \mathrm{m}^{-1} \cdot \mathrm{s}^{-2}\right)$ ). Both proteins showed similar enzymatic activity on the samples. rhDNase and PEG40-rhDNase groups were compared to the control group (one-way ANOVA, Bonferroni post-test, ${ }^{* *} p<$ $0.01, * p<0.05)$.

Our data were then categorized to correlate the enzymatic activity of both enzymes with the macroscopic appearance of the CF sputa. To the best of our knowledge, our investigation is the first to integrate the purulence parameter in the analysis of rhDNase mucolytic activity in CF sputa. Among the eighteen samples, twelve were purulent, five were muco-purulent and one was mucoid. Although not confirmed by the statistical analysis, a trend was observed between purulence and viscoelasticity of the sputum: the more purulent, the more elastic and the more viscous the sputum (Figure 2A and B). rhDNase and PEG40-rhDNase showed similar activity whether expectorations were purulent, muco-purulent or mucoid (Figure 2C and D). Overall, our rheological results showed that PEGylation preserved the mucolytic activity of rhDNase ex vivo. A large variation amongst samples was observed, potentially explained by variations in water, DNA, actin and glycoprotein content in CF sputa (23).

A

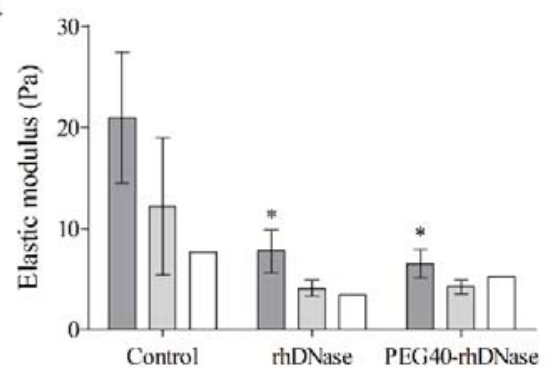

C

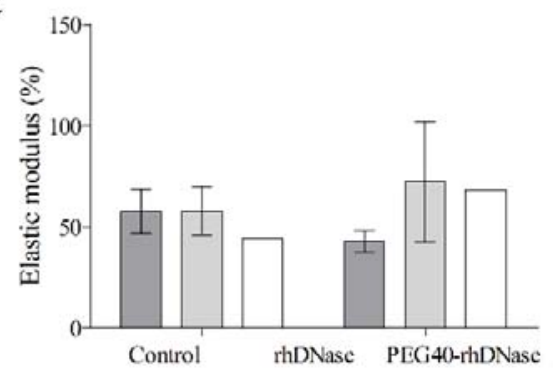

B

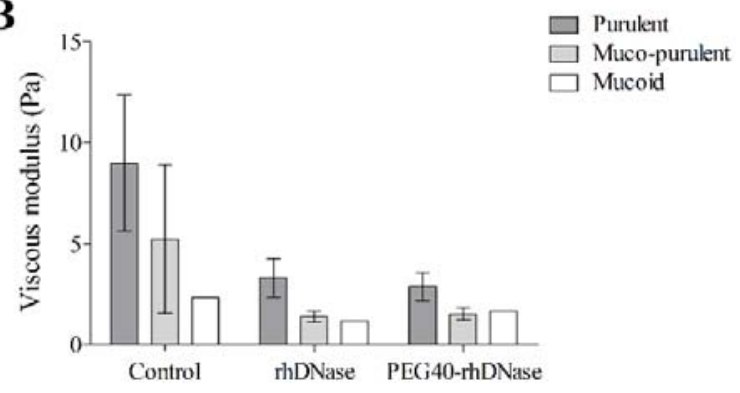

D

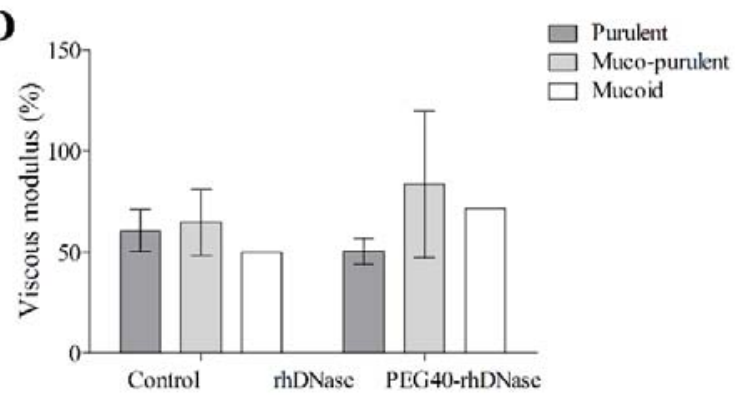

Figure 2: Effect of rhDNase and PEG40-rhDNase on the viscoelasticity of CF sputa based on the macroscopic appearance of the samples (mean $\pm S E M$ ). In $\boldsymbol{A}$ and $\boldsymbol{B}$, absolute values of elastic and viscous moduli are shown. In $\boldsymbol{C}$ and $\boldsymbol{D}$, elastic and viscous moduli are expressed as \% of the control samples. The data were compared by two way-ANOVA with no difference 
seen for purulent ( $n=12)$, muco-purulent $(n=5)$ and mucoid $(n=1)$ samples. The elastic modulus of purulent samples significantly decreased after treatment with rhDNase or PEG40-rhDNase (Bonferroni post-test, * $p<0.05$ ).

rhDNase or PEG40-rhDNase contained in CF sputa after rheology measurement were quantified (Figure 3). This analysis allowed us to evaluate the degradation of the proteins after incubation in the fluid. rhDNase and PEG40-rhDNase were initially added to CF sputum at a concentration of $10 \mu \mathrm{g} / \mathrm{mL}$. Following incubation and rheology, $27 \mathrm{ng} / \mathrm{mL}$ and $658 \mathrm{ng} / \mathrm{mL}$ of rhDNase and PEG40-rhDNase were measured in CF sputa, respectively. Therefore, $6.6 \%$ of the initial dose of PEG40-rhDNase remained after incubation with the sample whereas only $0.3 \%$ of rhDNase was measured, suggesting a higher stability of PEG40-rhDNase than the unconjugated protein. Accordingly, these results suggested that PEGylation increased the resistance of rhDNase towards proteolysis (37). Although the higher stability of PEG40-rhDNase in CF sputa did not result in major differences in mucolytic activity in our static assay ex vivo (Figure 1), it might result in better mucolytic activity in patients in vivo due to continuous DNA production.

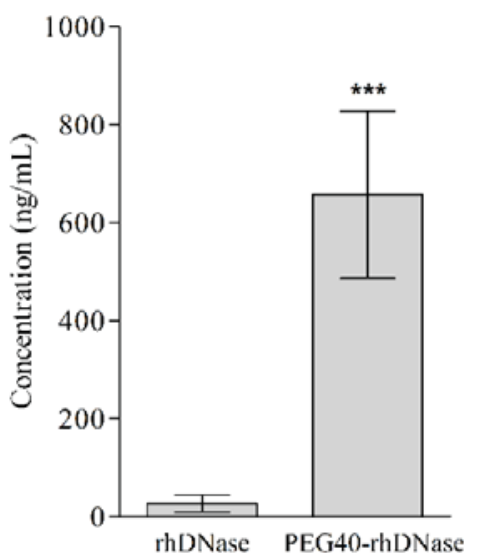

Figure 3: Quantification of rhDNase and PEG40-rhDNase remaining in sputa from patients with CF following rheology measurement of their mucolytic activity ( $n=11$ to 13$)$. rhDNase and PEG40-rhDNase contents in samples showed significant difference (unpaired t test, *** $p<0.001$ ).

\subsection{DNA quantification}

Extracellular DNA contained in sputum samples was quantified and compared to the visual aspect of the expectorations (Figure 4). This DNA quantification analysis included 25 samples. Fifteen were purulent, nine were muco-purulent and one was mucoid. The concentration of DNA in the samples was on average $0.80 \mathrm{mg} / \mathrm{mL}$ (values between 0.05 and $2.00 \mathrm{mg} / \mathrm{mL}$ ) and represented approximately $0.06 \%$ of the sputum mass. In mucus samples obtained from healthy patients, DNA accounts for $0.02 \%$ of the mucus by mass (16). Therefore, the DNA content in CF sputum was three-fold higher than in normal mucus. The aspect of the sputa correlated with the determined DNA concentration of each expectoration: the higher the concentration of DNA, the more purulent the sample. However, no correlation could be established between the DNA content and the elastic and viscous moduli of the samples (Figure 5). The ability of rhDNase and PEG40-rhDNase to reduce G' and G' of CF sputa reported above (Figure 1) confirms that DNA is a component responsible for the considerable viscoelasticity of diseased sputum, as previously reported by Shak and co-workers (33). However, the lack of correlation between DNA content and sputum viscoelasticity (Figure 5) indicates that DNA is not the only parameter involved (26). 


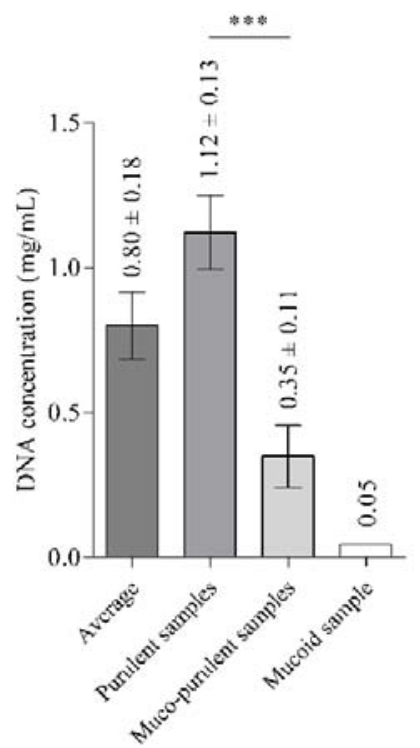

Figure 4: Quantification of extracellular DNA in CF sputa $(n=25$, mean \pm SEM). An apparent correlation is visible between the visual aspect of the sample and the concentration of DNA. DNA content in purulent and muco-purulent samples showed significant difference (unpaired t test, $* * * p<0.001$ ).
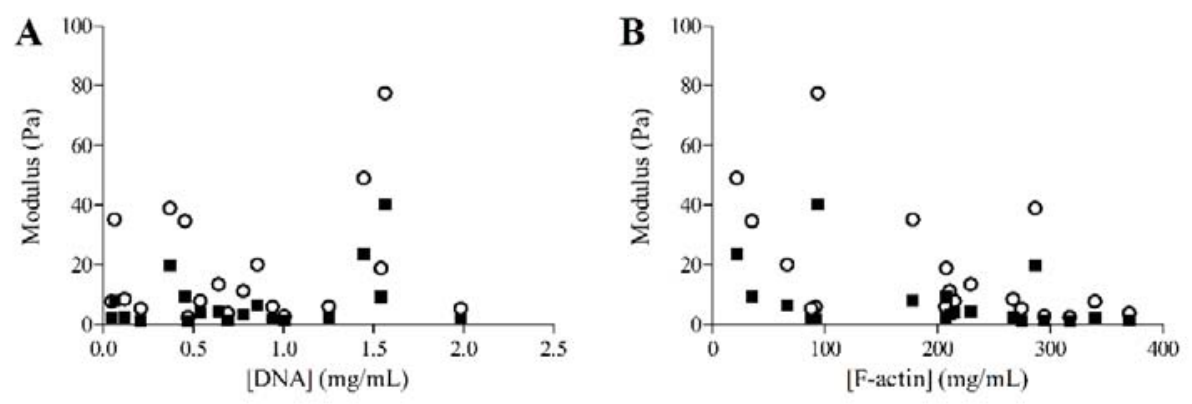

Figure 5: Influence of DNA (A) and F-actin (B) concentration of CF sputa on elastic and viscous moduli of the samples. No correlation was established (Pearson test, $p>0.05$ ).

\subsection{Actin quantification}

Globular actin (G-actin) is a potent inhibitor of rhDNase (17). We might expect an improved enzymatic activity of PEG40-rhDNase in the presence of actin compared with the unconjugated protein. In fact, PEG is known to prevent the approach of any other proteins, as G-actin and proteases, near the PEGylated protein due to the flexibility and hydration of the polymer and the steric hindrance it creates (37). However, PEG40-rhDNase was inhibited by actin to the same extent as rhDNase was (Figure 6), indicating that the actin-binding and PEGylation sites (N-terminus, (11)) were not sufficiently close to each other (Figure 6C). G-actin and rhDNase form a stoichiometric 1:1 complex with high affinity (dissociation constant of $30 \mathrm{nM}(4)$ ) and PEG might not prevent their association unless it is present within the binding interface. 
A

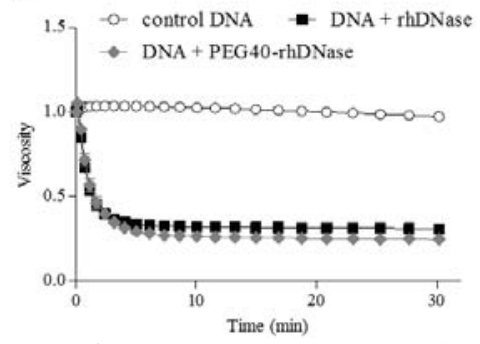

B

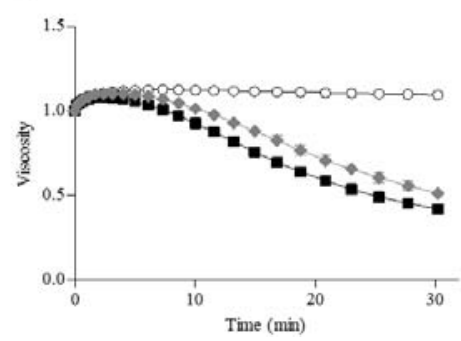

C

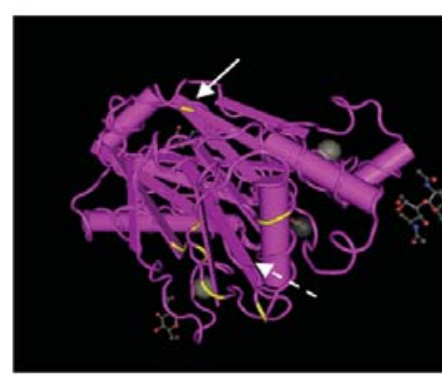

348

350

351

352

353

354

355

356

357

358

359

360

361

362

363

364

365

366

367

368

369

370

371

372

Figure 6: Viscosity analysis of DNA (A) and DNA containing actin (B) solutions following incubation with rhDNase or PEG40 rhDNase ( $n=5$, data were normalized to the time zero DNA viscosity for each protein). A kinetic evaluation of the enzymatic activity of each protein was recorded over $30 \mathrm{~min}$ and showed to be identical for both proteins in absence or presence of actin (two way-ANOVA, $p$ > 0.05). Actin inhibition of rhDNase and PEG40-rhDNase is illustrated in B. C. 3D structure of rhDNase (4AWN from the Protein Data Bank). The N-terminal leucine (at the surface of the protein; full line arrow) and the amino acids of rhDNase interacting with globular actin (at the surface of the protein; dotted line arrow) are indicated. Calcium (grey balls) and magnesium (black ball) ions are represented as well as $N$-acetyl-s-glucosamine (skeletal organic structure on the right), 2-[bis-(2-hydroxy-ethyl)-amino]-2-hydroxymethyl-propane-1,3-diol (skeletal organic structure on bottom) and phosphate ion (linked to magnesium ion) (25).

Because G-actin inhibited both rhDNase and PEG40-rhDNase in vitro, we quantified it in CF sputa in order to see whether mucolytic activities inversely correlate with G-actin content. The specific binding of rhodamine-labelled phalloidin to filamentous actin (F-actin) was used to measure the content of the different forms of actin in the sputa. The $25 \mathrm{CF}$ sputa contained on average $91 \mu \mathrm{g} / \mathrm{mL}$ of G-actin and $180 \mu \mathrm{g} / \mathrm{mL}$ of F-actin (Figure 7). Overall, all samples contained similar quantities of total actin (G+F actin; Figure 7). The quantity of G-actin in the sputa appeared to be linked to their visual aspect as a correlation was visible between purulence and G-actin content. The F-actin content did not correlate with the elastic and viscous moduli of samples (Figure 5), as it could have been expected (13). Moreover, no correlation was established between the concentration of G-actin and the activity of rhDNase, highlighting that rhDNase and PEGylated rhDNase were active to the same extent whatever the content of G-actin in the sputum (Figure 8). Therefore, the role of G-actin in the reduction of rhDNase efficacy was not verified in our ex vivo evaluation. Overall, rhDNase and PEG40-rhDNase therapies in CF sputa both showed positive outcomes (Figure 1).

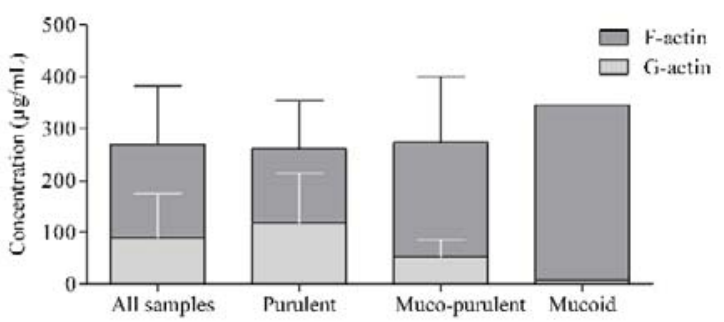

Figure 7: G-actin and F-actin quantification in CF sputa $(n=25$, mean \pm SEM). An apparent correlation is visible between the purulence of the sample and the concentration of G-actin. 
A

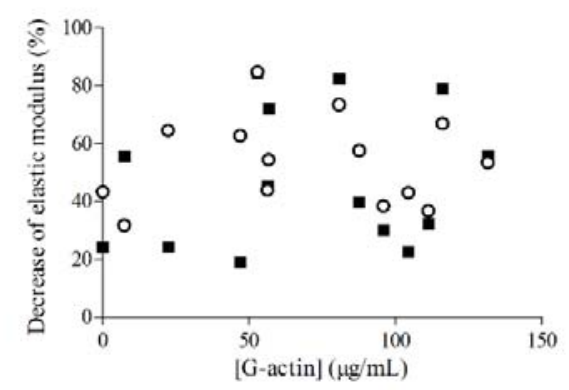

B

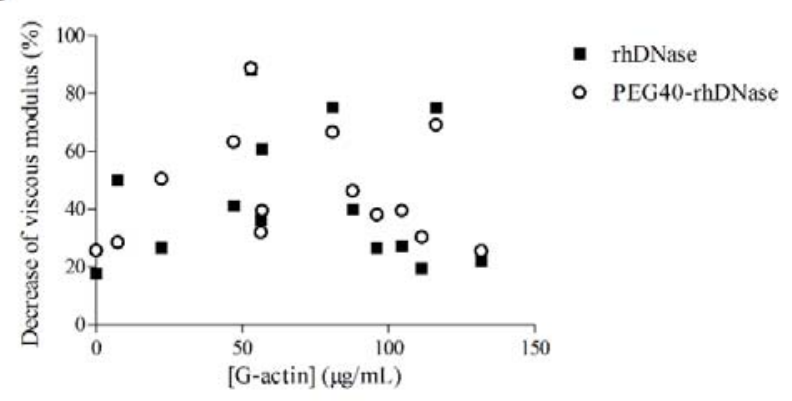

Figure 8: Influence of G-actin content on the activity of rhDNase and PEG40-rhDNase in CF sputa. Elastic (A) and viscous (B) moduli. No correlation was established between G-actin concentration and decrease of elastic or viscous modulus following addition of rhDNase or PEG40-rhDNase (Pearson test, $p>0.05$ ).

\subsection{Ions quantification}

Divalent metal ions such as $\mathrm{Ca}^{2+}$ and $\mathrm{Mg}^{2+}$ are required for the activity of rhDNase (21). Therefore, $\mathrm{CF}$ sputa were analyzed for ions content $\left(\mathrm{Ca}^{2+}, \mathrm{Mg}^{2+}\right.$ and $\left.\mathrm{K}^{+}\right)$. Mean values, also taking into account the purulence of samples, are shown in Table 1. In 1984, Kilbourn already analyzed the composition of sputa from patients with $\mathrm{CF}$ and reported that, over a total of 12 patients, samples contained $1.1 \pm 0.2$ $\mathrm{mM}$ of $\mathrm{Ca}^{2+}, 0.14 \pm 0.01 \mathrm{mM}$ of $\mathrm{Mg}^{2+}$ and $28 \pm 2 \mathrm{mM}$ of $\mathrm{K}^{+}$(14). More recently, Sanders et al. quantified $\mathrm{Ca}^{2+}, \mathrm{Mg}^{2+}$ and $\mathrm{K}^{+}$in sputa from clinical and clinical non-responders to rhDNase treatment (30). Samples from clinical responders contained $3.0 \mathrm{mM}$ of $\mathrm{Ca}^{2+}, 2.0 \mathrm{mM}$ of $\mathrm{Mg}^{2+}$ and $22 \mathrm{mM}^{2} \mathrm{~K}^{+}$. Clinical nonresponders sputa were also characterized by a $\mathrm{Ca}^{2+}$ concentration of $3.0 \mathrm{mM}$ but presented lower $\mathrm{Mg}^{2+}$ and $\mathrm{K}^{+}$contents with concentrations of $1.3 \mathrm{mM}$ and $18 \mathrm{mM}$, respectively. Except for the one-order of magnitude increase in magnesium concentration, our data were in good agreement with the values obtained by Kilbourn. Compared to Sanders et al. data, our results showed similar concentrations of $\mathrm{Mg}^{2+}$ and $\mathrm{K}^{+}$and lower content of $\mathrm{Ca}^{2+}$. We sorted the samples based on their visual aspect (Table 1) and showed that $\mathrm{Mg}^{2+}$ concentration was not linked to the purulence of the sputa. Also, no correlation was seen for calcium and potassium ions.

Table 1: Quantities of $\mathrm{Ca}^{2+}, \mathrm{Mg}^{2+}$ and $\mathrm{K}^{+}$found in $\mathrm{CF}$ sputa. Similar concentrations were measured in purulent ( $\left.\mathrm{n}=14\right)$, mucopurulent $(n=8)$ and mucoid $(n=1)$ samples. Data presented are mean $\pm S E M$.

\begin{tabular}{llll}
\hline Purulence & {$\left[\mathrm{Ca}^{2+}\right](\mathrm{mM})$} & {$\left[\mathrm{Mg}^{2+}\right](\mathrm{mM})$} & {$\left[\mathrm{K}^{+}\right](\mathrm{mM})$} \\
\hline Purulent & $1.4 \pm 0.2$ & $2.2 \pm 0.2$ & $24 \pm 1$ \\
Muco-purulent & $1.8 \pm 0.2$ & $1.9 \pm 0.2$ & $26 \pm 3$ \\
Mucoid & 1.4 & 1.8 & 22 \\
Average & $\mathbf{1 . 5} \pm \mathbf{0 . 2}$ & $\mathbf{2 . 1} \pm \mathbf{0 . 2}$ & $\mathbf{2 4} \pm \mathbf{1}$ \\
\hline
\end{tabular}

\subsection{Relationships between the different sputum parameters}

We demonstrated that the more purulent the sputum, the higher the DNA and G-actin contents (Figure 4 and Figure 7). However, our results did not show any significant correlation between the viscoelastic properties of the sputum and the concentration of DNA and F-actin (Figure 5). Moreover, we demonstrated that rhDNase and PEG40-rhDNase were active whatever the G-actin content (Figure 8). To further strengthen our analysis, we assessed the possible link between rhDNase or PEG40-rhDNase enzymatic activity and ions sputum contents.

$\mathrm{Ca}^{2+}$ and $\mathrm{Mg}^{2+}$ are involved in the stability and activity of rhDNase $(21,24)$. Therefore, concentrations of $\mathrm{Ca}^{2+}$ and $\mathrm{Mg}^{2+}$ were compared to the enzymatic activity of rhDNase (Figure 9). Results obtained showed that the activity of rhDNase on the elastic modulus of sputum inversely correlated with the content of $\mathrm{Ca}^{2+}$, suggesting that the higher the $\mathrm{Ca}^{2+}$ concentration, the lower the activity of rhDNase on G'. This finding is in contradiction with the fact that calcium ions are required for the stability and 
enzymatic activity of rhDNase (24). However, the activity of PEG40-rhDNase on elastic modulus of CF sputa did not depend on $\mathrm{Ca}^{2+}$ concentration. Also, the activity of both proteins on viscous modulus were independent on the concentrations of calcium and magnesium ions of CF sputa. Therefore, rhDNase and PEG40-rhDNase were active whatever these metal ion contents in sputa. Sanders et al., in their evaluation of the role of magnesium ions in the failure of rhDNase therapy in patients with CF, showed that the enzymatic activity of rhDNase correlated with the $\mathrm{Mg}^{2+}$ content in CF sputum (30). The authors defined three groups based on magnesium concentration: sputa containing $\left[\mathrm{Mg}^{2+}\right]>1.7 \mathrm{mM}$ were strongly degraded by rhDNase, sputa containing $1.4 \mathrm{mM}<\left[\mathrm{Mg}^{2+}\right]<1.7 \mathrm{mM}$ were weakly degraded by rhDNase and sputa containing $\left[\mathrm{Mg}^{2+}\right]<1.4 \mathrm{mM}$ were not degraded by rhDNase. However, we did not observe such a relationship (Figure 9). Overall, our results highlighted that both rhDNase and PEG40rhDNase were active whatever the $\mathrm{Mg}^{2+}$ concentration in CF sputa.

Moreover, the presence of metal ions in CF sputa such as magnesium and potassium promotes the formation of F-actin to the detriment of the globular form of actin (G-actin) (20). Our results demonstrated that no correlation could be established between the contents of $\mathrm{Mg}^{2+}$ and $\mathrm{K}^{+}$and G-actin concentration (Figure 10). Sanders et al. suggested that rhDNase activity in CF sputa was indirectly linked to the concentration of $\mathrm{Mg}^{2+}$ through the conformation of actin under the globular or filamentous form (30). Our results showed that G-actin concentration did not significantly correlate with the magnesium ions content found in CF sputa (Figure 10A), nor with rhDNase activity (Figure 8). Sanders et al. reported that both magnesium and potassium ions promote the polymerization of G-actin into Factin starting at concentrations of $0.4 \mathrm{mM}$ and $10 \mathrm{mM}$, respectively (30). Regarding the content of both ions found in our CF sputum samples $\left(2.11 \mathrm{mM}\right.$ for $\mathrm{Mg}^{2+}$ and $24 \mathrm{mM}$ for $\left.\mathrm{K}^{+}\right)$, our data are in good agreement with the fact that, at such $\mathrm{Mg}^{2+}$ and $\mathrm{K}^{+}$concentrations, more F-actin than $\mathrm{G}$-actin is present in CF sputum (Figure 7). However, purulent, muco-purulent and mucoid samples contained similar $\mathrm{Mg}^{2+}$ and $\mathrm{K}^{+}$concentrations but different $\mathrm{G}$-actin content, suggesting that $\mathrm{Mg}^{2+}$ and $\mathrm{K}^{+}$ions might not be the only parameters that influence the polymerization of G-actin in vivo. ability of both proteins to degrade the sputum was not dictated by the concentration of any parameter measured (DNA, G-actin, $\mathrm{Ca}^{2+}, \mathrm{Mg}^{2+}$ and $\mathrm{K}^{+}$).

A

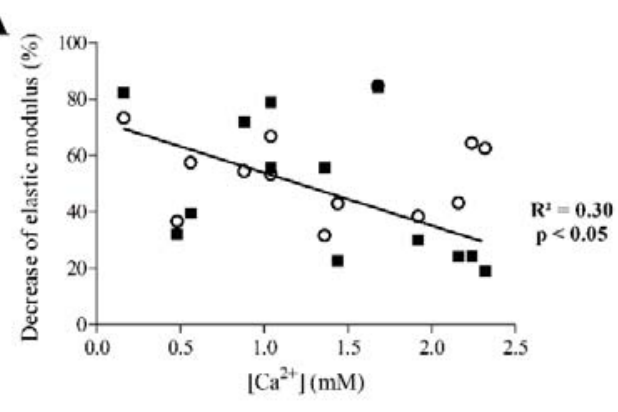

C

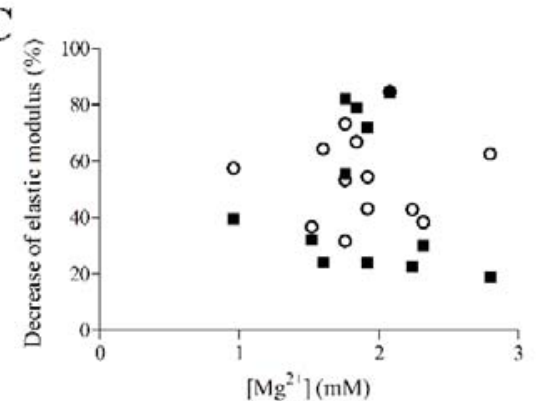

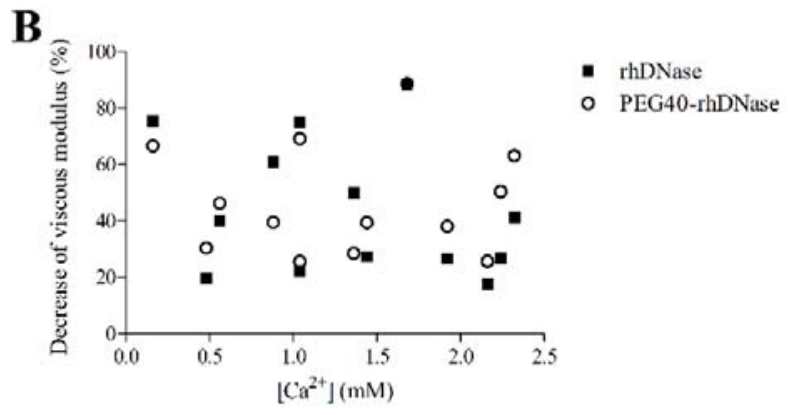

D

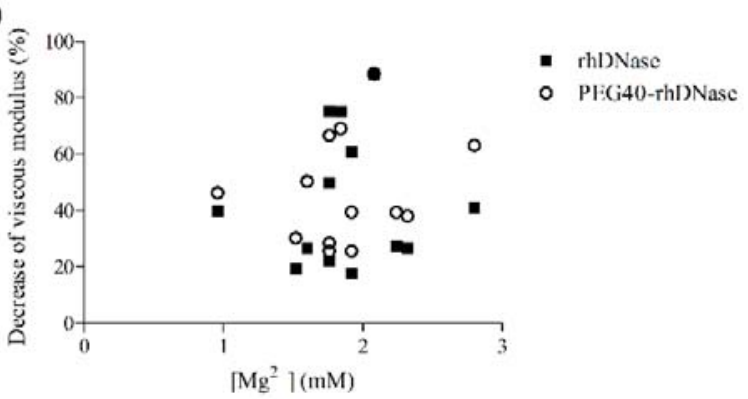

Figure 9: Influence of $\mathrm{Ca}^{2+}(\boldsymbol{A}$ and $\mathbf{B})$ and $\mathrm{Mg}^{2+}(\boldsymbol{C}$ and $\boldsymbol{D})$ contents in CF sputa on the activity of rhDNase and PEG40rhDNase. A significant correlation was only verified for calcium ions concentration and the activity of rhDNase on the elastic part of the samples (A, Pearson test, $p<0.05)$. No correlation was established between $\mathrm{Ca}^{2+}$ and decrease of elastic modulus nor between $\mathrm{Mg}^{2+}$ and decrease of elastic or viscous modulus following addition of rhDNase or PEG40-rhDNase (Pearson test, $p>0.05$ ). 
A

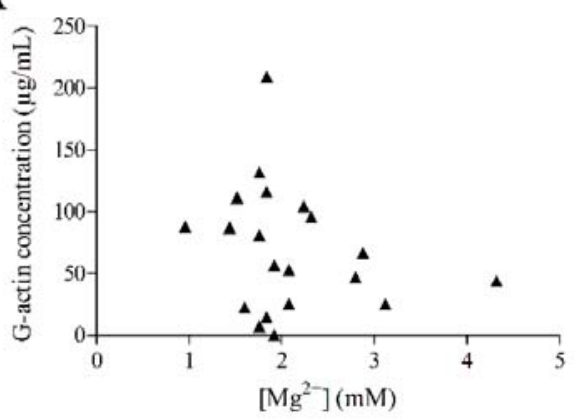

B

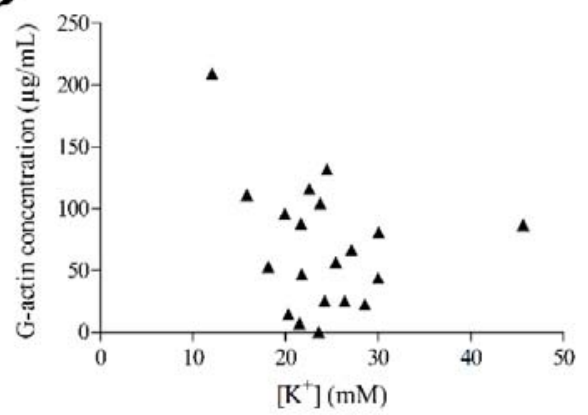

Figure 10: Influence of $\mathrm{Mg}^{2+}(\mathbf{A})$ and $\mathrm{K}^{+}$(B) contents on G-actin concentration in CF sputa. No correlation was established for both ions (Pearson test, $p>0.05$ ).

\section{Conclusion}

Since rheological methods can directly assess the efficacy of mucolytic agents, PEG40-rhDNase and rhDNase were evaluated in terms of enzymatic activity in CF sputa in order to predict the therapeutic value of the PEGylated protein. This clinical evaluation indicated that PEGylation preserved the mucolytic activity of rhDNase since both PEG40-rhDNase and the unconjugated enzyme induced a similar decrease of elastic and viscous moduli of the sputa. Concentrations of rhDNase remaining in $\mathrm{CF}$ sputa following one hour incubation at $37^{\circ} \mathrm{C}$ and rheology indicated that PEGylation increased rhDNase stability in respiratory secretions. DNA and G-actin quantities found in CF sputa were linked to the visual inspection of samples: the more purulent the sputum, the higher the DNA and G-actin concentrations. Overall, both rhDNase and PEG40-rhDNase were active whatever the DNA content of the CF sputum. Similarly, metal ions concentrations did not interfere with the activity of rhDNase, PEGylated or not. In vitro analysis showed that rhDNase and PEG40-rhDNase were partially inhibited by G-actin, but ex vivo evaluation of their mucolytic activity in CF sputa highlighted that PEGylation preserved rhDNase activity, independently of the content of G-actin in the sample. These results provide support to the development of a long-acting version of rhDNase to treat CF lung disease. 


\section{References}

1. Broughton-Head VJ, Shur J, Carroll MP, Smith JR, Shute JK. Unfractionated heparin reduces the elasticity of sputum from patients with cystic fibrosis. AJP Lung Cell Mol Physiol 293: L1240-L1249, 2007.

2. Broughton-Head VJ, Smith JR, Shur J, Shute JK. Actin limits enhancement of nanoparticle diffusion through cystic fibrosis sputum by mucolytics. Pulm Pharmacol Ther 20: 708-717, 2007.

3. Cantin AM, Woods DE, Cloutier D, Dufour EK, Leduc R. Polyethylene Glycol Conjugation at Cys 232 Prolongs the Half-Life of a 1 Proteinase Inhibitor. Am J Respir Cell Mol Biol 27: 659-665, 2002.

4. Carter LK, Christopherson RI, dos Remedios CG. Analysis of the binding of deoxyribonuclease I to G-actin by capillary electrophoresis. Electrophoresis 18: 1054-1058, 1997.

5. Crowther RS, Marriott C, James SL. Cation induced changes in the rheological properties of purified mucus glycoprotein gels. [Online]. Biorheology 21: 253-63, 1984. http://www.ncbi.nlm.nih.gov/pubmed/6466792 [16 Jun. 2017].

6. Davis PB. Cystic Fibrosis Since 1938. Am J Respir Crit Care Med 173: 475-482, 2006.

7. Dwyer M, Shan Q, D'Ortona S, Maurer R, Mitchell R, Olesen H, Thiel S, Huebner J, Gadjeva M. Cystic Fibrosis Sputum DNA Has NETosis Characteristics and Neutrophil Extracellular Trap Release Is Regulated by Macrophage Migration-Inhibitory Factor. J Innate Immun 6: 765-779, 2014.

8. $\quad$ Fahy J V., Dickey BF. Airway Mucus Function and Dysfunction. $N$ Engl J Med 363: 22332247, 2010.

9. Freches D, Patil HP, Franco MM, Uyttenhove C, Heywood S, Vanbever R. PEGylation prolongs the pulmonary retention of an anti-IL-17A Fab' antibody fragment after pulmonary delivery in three different species. Int. J. Pharm. (2017). doi: 10.1016/j.ijpharm.2017.02.021.

10. Galabert C, Jacquot J, Zahm JM, Puchelle E. Relationships between the lipid content and the rheological properties of airway secretions in cystic fibrosis. [Online]. Clin Chim Acta 164: 13949, 1987. http://www.ncbi.nlm.nih.gov/pubmed/3594907 [16 Jun. 2017].

11. Guichard M-J, Patil HP, Koussoroplis SJ, Wattiez R, Leal T, Vanbever R. Production and characterization of a PEGylated derivative of recombinant human deoxyribonuclease I for cystic fibrosis therapy. Int. J. Pharm. (2017). doi: 10.1016/j.ijpharm.2017.03.057.

12. Invitrogen. Quant-i $\mathrm{T}^{\mathrm{TM}}$ PicoGreen ${ }^{\circledR}$ dsDNA Reagent and Kits [Online]. 2008. https://tools.thermofisher.com/content/sfs/manuals/mp07581.pdf [26 Apr. 2017]. 
13. Kater A, Henke MO, Rubin BK. The Role of DNA and Actin Polymers on the Polymer Structure and Rheology of Cystic Fibrosis Sputum and Depolymerization by Gelsolin or Thymosin Beta 4. Ann N Y Acad Sci 1112: 140-153, 2007.

14. Kilbourn JP. Composition of sputum from patients with cystic fibrosis. Curr Microbiol 11: 1922, 1984.

15. Koussoroplis SJ, Paulissen G, Tyteca D, Goldansaz H, Todoroff J, Barilly C, Uyttenhove C, Van Snick J, Cataldo D, Vanbever R. PEGylation of antibody fragments greatly increases their local residence time following delivery to the respiratory tract. J Control Release 187: 91$100,2014$.

16. Lai SK, Wang Y-Y, Wirtz D, Hanes J. Micro- and macrorheology of mucus. Adv Drug Deliv Rev 61: 86-100, 2009.

17. Lazarides E, Lindberg $\mathbf{U}$. Actin is the naturally occurring inhibitor of deoxyribonuclease I.

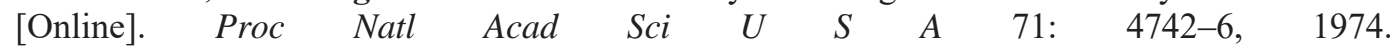
http://www.pubmedcentral.nih.gov/articlerender.fcgi?artid=433972\&tool=pmcentrez\&renderty pe $=$ abstract [29 Oct. 2014].

18. Lazarus RA, Wagener JS. Recombinant Human Deoxyribonuclease I [Online]. Pharm. Biotechnol. http://www.crcnetbase.com/doi/abs/10.3109/9781420044386-20 [29 Jan. 2016].

19. Marriott C, Beeson MF, Brown DT. Biopolymer Induced Changes in Mucus Viscoelasticity. Springer US, p. 89-92.

20. Maruyama K, Tsukagoshi $\mathbf{K}$. Effects of $\mathrm{KCl}, \mathrm{MgCl} 2$, and $\mathrm{CaCl} 2$ concentrations on the monomer-polymer equilibrium of actin in the presence and absence of cytochalasin D. [Online]. J Biochem 96: 605-11, 1984. http://www.ncbi.nlm.nih.gov/pubmed/6444205 [16 Jun. 2017].

21. Moore S. Pancreatic DNase. Enzym 3rd ed Acad Press NY 13: 281-296, 1981.

22. Mrsny R, Daugherty A, Short S, Widmer R, Siegel M, Keller G-A. Distribution of DNA and Alginate in Purulent Cystic Fibrosis Sputum: Implications to Pulmonary Targeting Strategies. $J$ Drug Target 4: 233-243, 1996.

23. Nielsen H, Hvidt S, Sheils CA, Janmey PA. Elastic contributions dominate the viscoelastic properties of sputum from cystic fibrosis patients. Biophys Chem 112: 193-200, 2004.

24. Pan CQ, Lazarus RA. Ca2+-dependent activity of human DNase I and its hyperactive variants. Protein Sci 8: 1780-8, 1999.

25. Parsiegla G, Noguere C, Santell L, Lazarus RA, Bourne Y. The structure of human DNase I bound to magnesium and phosphate ions points to a catalytic mechanism common to members 
of the DNase I-like superfamily. Biochemistry 51: 10250-8, 2012.

26. Picot R, Das I, Reid L. Pus, deoxyribonucleic acid, and sputum viscosity. [Online]. Thorax 33: 235-42, 1978. http://www.ncbi.nlm.nih.gov/pubmed/26989 [10 Aug. 2017].

27. Potter J, Matthews L, Spector S, Lemm J. Studies on pulmonary secretions. II. Osmolality and the ionic environment of pulmonary secretions from patients with cystic fibrosis, bronchiectasi... - PubMed - NCBI. Am Rev Respir Dis 91: 83-87, 1967.

28. Puchelle E, Zahm JM, Duvivier C, Didelon J, Jacquot J, Quemada D. Elasto-thixotropic properties of bronchial mucus and polymer analogs. I. Experimental results. [Online]. Biorheology 22: 415-23, 1985. http://www.ncbi.nlm.nih.gov/pubmed/3830276 [10 Aug. 2017].

29. Rowe SM, Miller S, Sorscher EJ. Cystic Fibrosis. N Engl J Med 352: 1992-2001, 2005.

30. Sanders NN, Franckx H, De Boeck K, Haustraete J, De Smedt SC, Demeester J. Role of magnesium in the failure of rhDNase therapy in patients with cystic fibrosis. Thorax 61: 962-8, 2006.

31. Serisier DJ, Carroll MP, Shute JK, Young SA, Matsui H, Grubb B, Tarran R, Randell S, Gatzy J, Davis C, Boucher R, Tarran R, Grubb B, Parsons D, Picher M, Hirsh A, Davis C, Boucher R, Puchelle E, Bentzmann S De, Zahm J, Powell K, Zeitlin P, Ramsey B, King M, Charman J, Reid L, Picot R, Das I, Reid L, Lethem M, James S, Marriott C, Balfour-Lynn I, Klein N, Dinwiddie R, Broughton-head V, Carroll M, Shute J, Jeanneret-Grosjean A, Michoud M, King M, Liote H, Amyot R, Sanders N, Smedt S de, Rompaey E van, Simoens P, Baets F de, Demeester J, Paggiaro P, Chanez P, Holz O, Ind P, Djukanovic R, Maestrelli P, Sterk P, Baldrey P, Josse S, Broughton-Head V, Smith J, Shur J, Shute J, Suri R, Marshall L, Wallis C, Metcalfe C, Bush A, Shute J, Stockley R, Bayley D, Hill S, Hill A, Crooks S, Campbell E, Deneuville E, Perrot-Minot C, Pennaforte F, Roussey M, Zahm J, Clavel C, Puchelle E, Bentzmann S de, Kim J, Okamoto K, Rubin K, McShane D, Davies J, Wodehouse T, Bush A, Geddes D, Alton D, Bush A, Payne D, Pike S, Jenkins G, Henke M, Rubin B, Perez A, Issler A, Cotton C, Kelley T, Verkmann A, Davis P, Goldmann M, Anderson G, Stolzenberg E, Kari U, Zasloff M, Wilson J, Bals R, Weiner D, Meegalla R, Accurso F, Wilson J, Moskwa P, Lorentzen D, Excoffon K, Zabner J, McCRay PJ, Nauseef W, Dupuy C, Banfi B, Caramori G, Gregorio C Di, Carlstedt I, Casolari P, Guzzinati I, Adcock I, Barnes P, Ciaccia A, Cavallesco G, Chung K, Papi A, Rogers D, Barnes P, Henke M, Renner A, Huber R, Seeds M, Rubin B, Inoue D, Kubo H, Sasaki T, Yasuda H, Numasaki M, Sasaki H, Yamaya M, Ou X, Feng Y, Wen F, Wang K, Yang J, Deng Z, Liu D, Li Y, King M, Dasgupta B, Tomkiewicz R, Brown N, Albertini-Yagi C, Oliveira R, Vieira J, Negri E, Oliveira L de, Saldiva P, Lorenzi-Filho G, Baconnais S, Tirouvanziam R, Zahm J, Bentzmann S de, Peault B, Balossier G, Puchelle E. Macrorheology of cystic fibrosis, chronic obstructive pulmonary disease \&amp; normal sputum. Respir Res 10: 63, 2009.

32. Shah PL, Scott SF, Geddes DM, Hodson ME. Two years experience with recombinant Human DNase I in the treatment of pulmonary disease in cystic fibrosis. Respir Med 89: 499-502, 1995.

33. Shak S, Capon DJ, Hellmiss R, Marsters SA, Baker CL. Recombinant human DNase I reduces the viscosity of cystic fibrosis sputum. [Online]. Proc Natl Acad Sci U S A 87: 9188-92, 1990. http://www.ncbi.nlm.nih.gov/pubmed/2251263 [19 Dec. 2016]. 
34. Tirella A, Mattei G, Ahluwalia A. Strain rate viscoelastic analysis of soft and highly hydrated biomaterials. J Biomed Mater Res A 102: 3352-60, 2014.

35. Tomaiuolo G, Rusciano G, Caserta S, Carciati A, Carnovale V, Abete P, Sasso A, Guido S, O'Sullivan B, Freedman S, Davis P, Drumm M, Konstan M, Davis P, Vij N, Downey G, Maiuri L, Luciani A, Giardino I, Raia V, Villella V, Voter K, Ren C, Sheppard M, Nicholson A, Amato F, Bellia C, Cardillo G, Castaldo G, Ciaccio M, Tomaiuolo R, Fausto M, Elce A, Strina I, Ranieri A, Lai S, Wang Y-Y, Wirtz D, Hanes J, Lai S, Wang Y, Cone R, Wirtz D, Hanes J, Dawson M, Wirtz D, Hanes J, Stenbit A, Flume P, Tomaiuolo G, Barra M, Preziosi V, Cassinese A, Rotoli B, Tomaiuolo G, Guido S, Tomaiuolo G, Rossi D, Caserta S, Cesarelli M, Guido S, Tomaiuolo G, Lanotte L, Ghigliotti G, Misbah C, Guido S, Livak-Dahl E, Lee J, Burns M, Davis S, Dippy J, Jonás A, Luca A De, Pesce G, Rusciano G, Sasso A, King M, Macklem P, King M, Dasgupta B, Tomkiewicz R, Brown N, Feng W, Garrett H, Speert D, King M, Celli J, Gregor B, Turner B, Afdhal N, Bansil R, Minale M, Caserta S, Guido S, Serisier D, Carroll M, Shute J, Young S, Caserta S, Simeone M, Guido S, Caserta S, Guido S, Caserta S, Sabetta L, Simeone M, Guido S, Jolliffe I, Vandenginste B, Massart D, Buydens L, Jong S de, Lewi P, Cone R, Gilligan P, Harrison F, Waters V, Yau Y, Prasad S, Lu A, Atenafu E, Jong B de, Schut TB, Maquelin K, Kwast T van der, Bangma C, Amato F, Seia M, Giordano S, Elce A, Zarrilli F, Giordano S, Amato F, Elce A, Monti M, Iannone C. A New Method to Improve the Clinical Evaluation of Cystic Fibrosis Patients by Mucus Viscoelastic Properties. PLoS One 9: e82297, 2014.

36. Ulmer JS, Herzka A, Toy KJ, Baker DL, Dodge AH, Sinicropi D, Shak S, Lazarus RA. Engineering actin-resistant human DNase I for treatment of cystic fibrosis. [Online]. Proc Natl $\begin{array}{lllllll}\text { Acad } & S c i & U & S & \text { A } & \text { 93: }\end{array}$ http://www.pubmedcentral.nih.gov/articlerender.fcgi?artid=38651\&tool=pmcentrez\&rendertyp $\mathrm{e}=$ abstract [21 Oct. 2014].

37. Veronese FM, Pasut G. PEGylation, successful approach to drug delivery. Drug Discov Today 10: 1451-8, 2005. 